\title{
Study of electromotive force of a new type of membraneless fuel cell operating on renewable fuel
}

\author{
K. R. Tarantseva ${ }^{l, *}, M . I$. Yakhkind ${ }^{l}, A . V$. Korosteleva $^{l}, E$. G. Krasnaya $^{l}, E . A$. Parfenova $^{l}$, and $O . G$. Kurochkina ${ }^{l}$ \\ ${ }^{1}$ Penza State Technological University, Russia
}

\begin{abstract}
The possibility of using base metals and alloys based on them as electrodes for a new type of membraneless fuel cells operating on renewable fuel has been investigated. The phase boundary of two immiscible liquids in the ethanol-water-potassium hydroxide system plays a role of a membrane in these elements. Top phase of this fuel cell has significant alcohol content and insignificant electrolyte content, bottom phase has significant electrolyte content and insignificant alcohol content. Platinum- and rutheniumcoated titanium electrode, carbon electrode and stainless steel electrode were used as the anode. Stainless steel electrode and carbon steel electrode were used as the cathode. The possibility of using ferrous alloys as anode and cathode catalysts in this type of fuel cells is shown.
\end{abstract}

\section{Introduction}

Currently only membrane fuel cells have found practical use from the various types of fuel cells operating on renewable fuel (mainly ethanol). A porous membrane with an electrolyte is located between the anode and cathode in these fuel cells which conducts protons or hydroxide anions, but does not conduct electrons.

Practical use of most such fuel cells is limited due to high cost of their catalysts. At present, anodic and cathodic catalysts in acidic media based only on the noble metals Pt-Ru and Pt [1], with the exception of one work where a cathode catalyst based on $\mathrm{Ru}-\mathrm{Se}$ was used [2].

In alkaline media use of base metal catalysts is possible. However, in most cases in alkaline electrolyte anode catalysts based on $\mathrm{Pt}-\mathrm{Ru}$ or $\mathrm{Pt}$ are also used. Anode catalysts based on Pd (Pd, Pd-Sn-Ni [3], Pd-Ag [4], $\mathrm{Pd}-\mathrm{Cu}$ [5], Pd-NiO [6]) are described. Anode catalysts based on $\mathrm{Al}$ [7] and $\mathrm{Ni}(\mathrm{OH})_{2}$ is known [8]. But using of aluminum as anode is possible only in alkaline electrolyte obtained from anhydrous methanol. In aqueous methanol, aluminum rapidly dissolves to form $\mathrm{Al}(\mathrm{OH})_{3}$. Using of an anode based on $\mathrm{Ni}(\mathrm{OH})_{2}$ is possible in a conventional alkaline electrolyte.

Cathode catalysts for alkaline and acid electrolytes in most cases also were made mainly of platinum and its alloys, PtAu [9] and PtPd [10], and Ag [11]. Catalysts based on $\mathrm{Pt}-\mathrm{Mn}_{2} \mathrm{O}_{3}$ [12], $\mathrm{Ag}(\mathrm{AgO})$ [8], $\mathrm{Ag}-\mathrm{Pt}$ [13-15] and Ag-Sn [16] are known too.

Cathode catalysts based on $\mathrm{Fe}[3]$ and $\mathrm{NiCo}_{2} \mathrm{O}_{4}$, $\mathrm{MnNiCoO}_{4}$ [17] are described. It is noted that the electrochemical oxidation of alcohols does not occur on these catalysts. Fe-based cathode catalyst is used in conjunction with $\mathrm{Pd}$; Pd-Sn-Ni based anode catalysts. Thus, noble metals and alloys are mainly used as cathode and anode catalysts in fuel cells, which are not entirely justified for alkaline media.

In alkaline electrolyte the energy barrier to the oxygen reaction is reduced compared to the protonconducting electrolyte due to the peculiarities of the kinetics and thermodynamics of the oxygen reaction $[18$, 19]. As a result, even materials with relatively low oxygen adsorption energy can be used as sufficiently active catalysts for its reduction, which expands the range of possible catalytic systems. The possibilities of using new materials, not based on noble metals, in alkaline media of fuel cells have not yet been investigated.

In this regard, studying the possibility of using other corrosion-resistant materials in fuel cells is interest as scientific and practical point of view [20].

Our previous studies showed the possibility of using the ethanol-water-potassium hydroxide system as an electrolyte for a membraneless fuel cell based on two immiscible liquids. In the selected system (ethanol water - potassium hydroxide $\left(\mathrm{EtOH}-\mathrm{KOH}-\mathrm{H}_{2} \mathrm{O}\right)$, the phase boundary plays a role of a membrane.

In this work, we studied the electromotive force (EMF) of a membraneless fuel cell based on the selected system of liquids and electrodes made of various metals and alloys, including base metals.

\section{Materials and methods}

The fuel cell is a rectangular box with walls of $4 \mathrm{~mm}$ in thickness made of Plexiglas XT 20070. Internal dimensions are $150 \times 100 \times 50 \mathrm{~mm}$, and a nominal capacity is $750 \mathrm{~mL}$. Anodes and cathodes were changeable.

The following anodes are used:

\footnotetext{
* Corresponding author: $\underline{\operatorname{krtar} @ \text { bk.ru }}$
} 
- platinum-coated titanium electrode (thin layer of platinum on a perforated titanium net of $150 \times 100 \mathrm{~mm}$ in dimensions);

- ruthenium-coated titanium electrode (thin layer of ruthenium on a perforated titanium net of $150 \times 100 \mathrm{~mm}$ in dimensions);

-activated carbon electrode (in a wire basket made of stainless steel $18 \mathrm{Cr}-9 \mathrm{Ni}$ ), basket is $150 \times 95 \times 30 \mathrm{~mm}$ in dimensions, wire is $0.3 \mathrm{~mm}$ in diameter, meshes are 0.5 $\times 0.5 \mathrm{~mm}$ in dimensions, mass of the loaded carbon is $107 \mathrm{~g}$;

- stainless steel $(18 \mathrm{Cr}-9 \mathrm{Ni})$ wire net electrode of $150 \times$ $100 \mathrm{~mm}$ in dimensions, wire is $0.3 \mathrm{~mm}$ in diameter, meshes are $0.5 \times 0.5 \mathrm{~mm}$ in dimensions.

The following cathodes are used:

- stainless steel $(18 \mathrm{Cr}-9 \mathrm{Ni})$ wire net electrode of $150 \times$ $100 \mathrm{~mm}$ in dimensions, wire is $0.3 \mathrm{~mm}$ in diameter, meshes are $0.5 \times 0.5 \mathrm{~mm}$ in dimensions.

- low carbon steel $(0.1 \% \mathrm{C})$ wire net electrode of $150 \times$ $100 \mathrm{~mm}$ in dimensions, wire is $0.25 \mathrm{~mm}$ in diameter, meshes are $1 \times 1 \mathrm{~mm}$ in dimensions

A two-phase system (EtOH - 30\% m/m, KOH - 40\% $\mathrm{m} / \mathrm{m}, \mathrm{H}_{2} \mathrm{O}-30 \% \mathrm{~m} / \mathrm{m}$ ) was used in all experiments. The composition of the ethanol (top) phase: EtOH - 57\% $\mathrm{m} / \mathrm{m}, \mathrm{KOH}-28 \% \mathrm{~m} / \mathrm{m}, \mathrm{H}_{2} \mathrm{O}-15 \% \mathrm{~m} / \mathrm{m}, \mathrm{pH} 13.1$. The composition of the aqueous (bottom) phase: EtOH $0 \% \mathrm{~m} / \mathrm{m}, \mathrm{KOH}-50 \% \mathrm{~m} / \mathrm{m}, \mathrm{H}_{2} \mathrm{O}-50 \% \mathrm{~m} / \mathrm{m}, \mathrm{pH} 13.2$.

The volume of the two-phase system was $700 \mathrm{ml}$, including the bottom phase $250 \mathrm{ml}$, the top phase 450 $\mathrm{ml}$.

Potassium hydroxide (containing $90.0 \%$ of main substance) and ethanol (containing $4.0 \%$ of water) were used. The cell was purged with oxygen before the experiment.

Potential and current in the fuel cell were measured by the Elins P-30JM potentiostat-galvanostat (software ver. 3.90).

The experiments were carried out at a room temperature $20 \div 22^{\circ} \mathrm{C}$.

\section{Results and Discussion}

Change in EMF of a fuel cell with a platinum titanium anode located in the top phase and a carbon steel cathode in the bottom phase is showed on Fig. 1. EMF of the fuel cell decreases from $800 \mathrm{mV}$ to $600 \mathrm{mV}$ after 5 hours of operation in a natural aeration.

When replacing the carbon steel cathode with a stainless steel $(18 \mathrm{Cr}-9 \mathrm{Ni})$ cathode the fuel cell worked with an electromotive force of about $700 \mathrm{mV}$ (Fig. 2).

Subsequent monitoring of this system for 18 hours showed that the EMF in the system stabilized at $770 \mathrm{mV}$ (Fig. 3).

When using a ruthenium-coated anode instead of a platinum-coated anode, EMF of the fuel cell was 800 $\mathrm{mV}$ to $700 \mathrm{mV}$ during 3 hours of observation (Fig. 4).

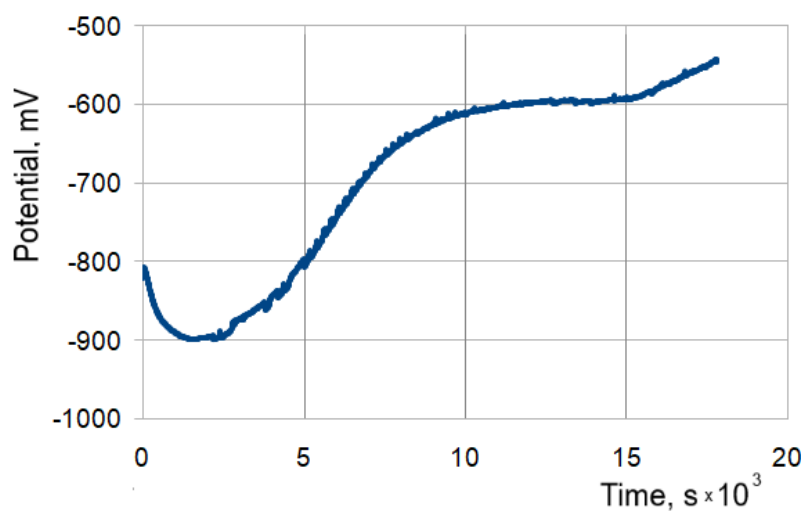

Fig. 1. Change in EMF of a fuel cell with a platinum-coated titanium anode and a carbon steel cathode.

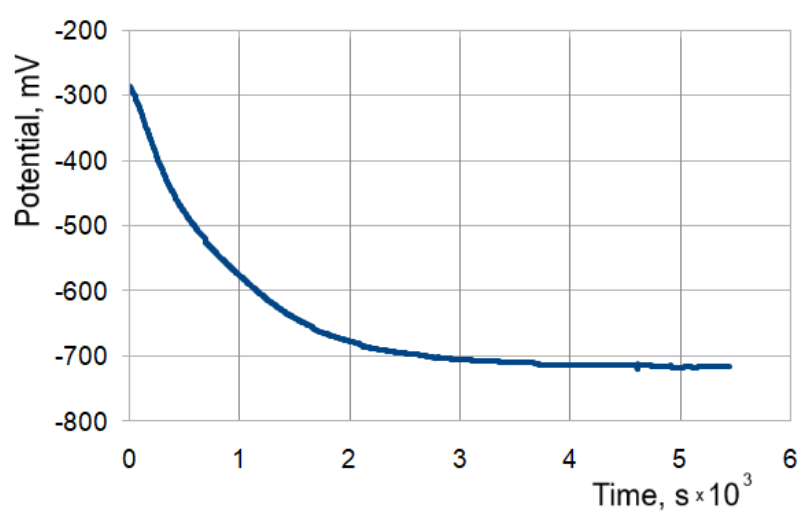

Fig. 2. Change in EMF of a fuel cell with a platinum-coated titanium anode and a stainless steel cathode, which replaced a carbon steel cathode.

Next, possibility of replacing platinum- and ruthenium-coated anodes on cheaper materials, in particular, activated carbon anode in a stainless steel (18Cr-9Ni) wire basket, was investigated.

Fig. 5 shows the change of EMF with time in such type of fuel cell. It can be seen that EMF for a given fuel cell is about $720 \mathrm{mV}$.

EMF of this system remained at the level of $730 \mathrm{mV}$ for a long time up to 24 hours (Fig. 6). The introduction of an oxidant (sodium hypochlorite) into the bottom phase in an amount of $2 \mathrm{ml}$ (first peak) and $3 \mathrm{ml}$ (second peak) only for a short time shifted the potential of carbon steel to the positive region, after which the system returned to its original state.

The initial introduction of $25 \mathrm{ml}$ of sodium hypochlorite into the bottom phase also did not practically change the value of EMF (Fig. 7).

The injection of potassium chromate solution $(0.72 \mathrm{~g}$ in $2 \mathrm{ml}$ of water) into the bottom phase after 11 minutes of operation of the fuel cell led to a decrease in the EMF of the system to $-350 \mathrm{mV}$, due to a decrease in the overvoltage of oxidant reduction (Fig. 8). 


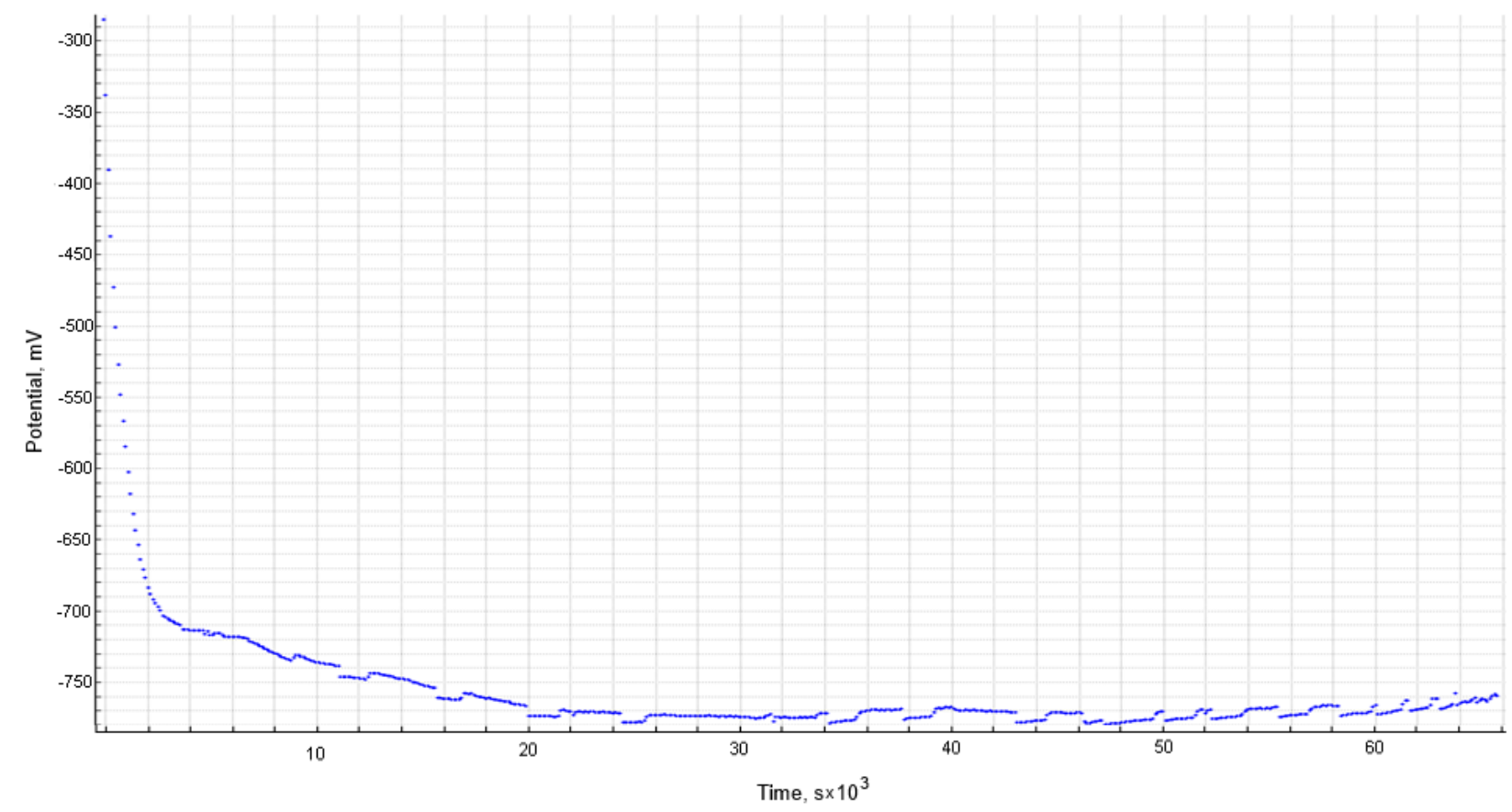

Fig. 3. Change in EMF of a fuel cell with a platinum-coated titanium anode and a stainless steel cathode, which replaced a carbon steel cathode, long monitoring.

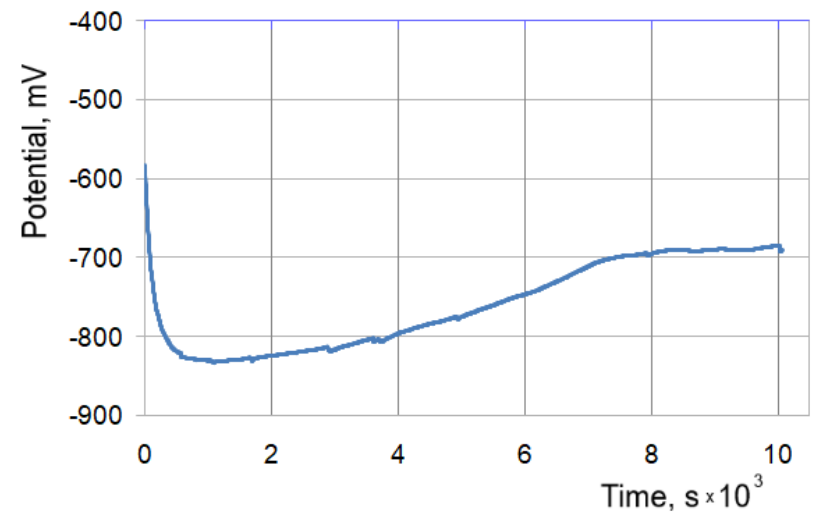

Fig. 4. Change in EMF of a fuel cell with a ruthenium-coated titanium anode and a carbon steel cathode.

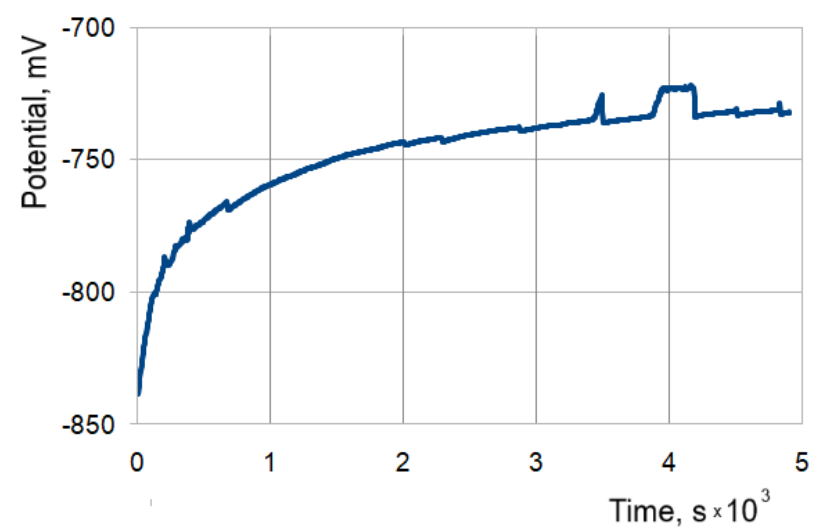

Fig. 5. Change in EMF of fuel cell with an activated carbon anode and a carbon steel cathode.

The possibility of using a carbon anode instead of platinum- and ruthenium-coated titanium anodes will significantly reduce the cost of manufacturing a fuel cell at almost the same and even greater power.

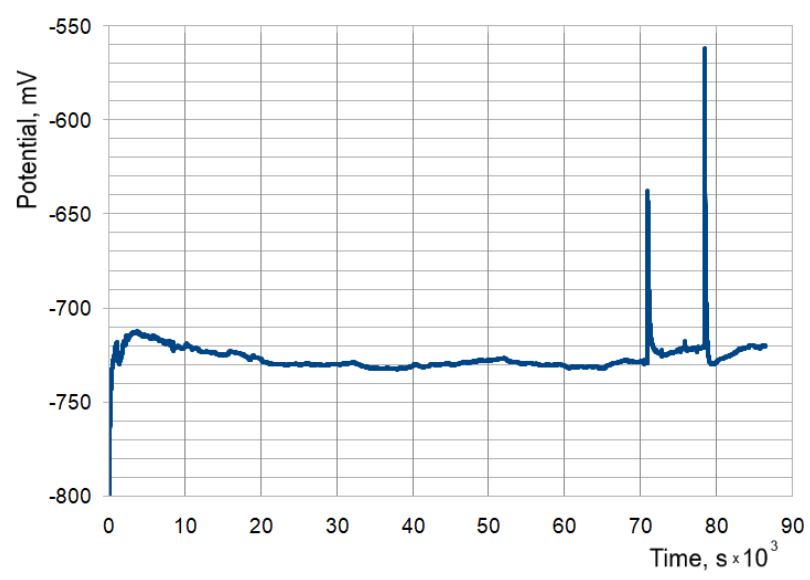

Fig. 6. Change in EMF of fuel cell with an activated carbon anode and a carbon steel cathode, introduction of sodium hypochlorite solution in the bottom phase: first peak $(2 \mathrm{ml})$, second peak $(3 \mathrm{ml})$.

It is necessary to continue research in this direction for choosing new materials to make electrodes and finding additional ways to intensify the processes occurring in the fuel cell, taking into account both the thermodynamics and kinetics of the processes.

Probability that stainless steel (18Cr-9Ni) electrode can be used as an anode without activated carbon, when carbon steel electrode is used as cathode, is significant. The results of the study showed that EMF in this system is up to $0.88 \mathrm{mV}$ (Fig. 9). In this connection, further research in this direction is necessary. 


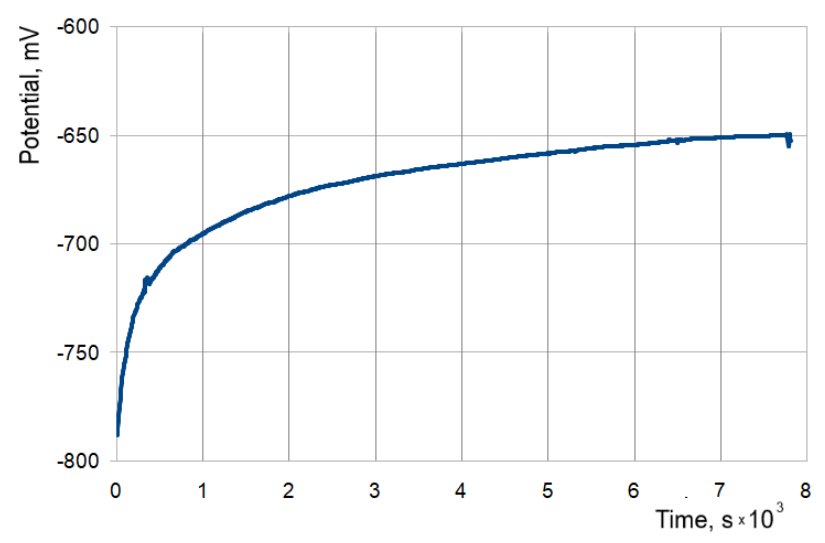

Fig. 7. Change in EMF of fuel cell with an activated carbon anode and a carbon steel cathode, initial introduction of sodium hypochlorite solution $(25 \mathrm{ml})$ in the bottom phase.

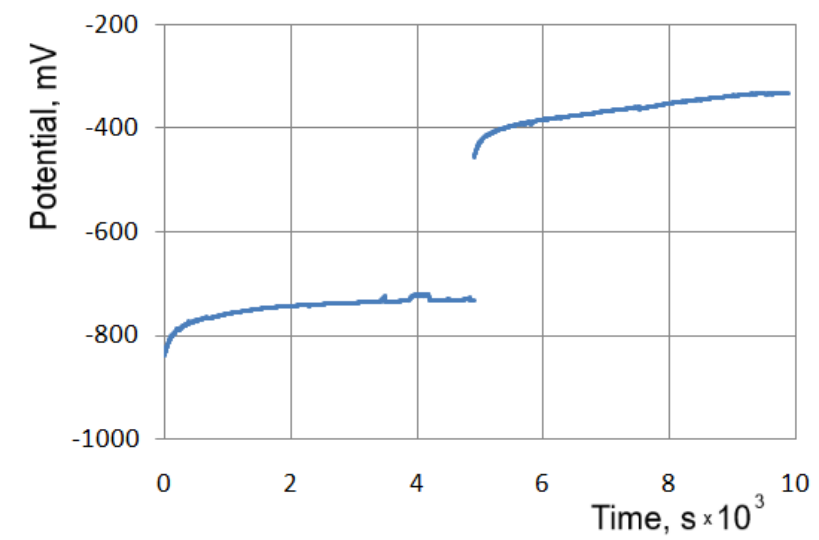

Fig. 8. Change in EMF of fuel cell with an activated carbon anode and a carbon steel cathode, addition of potassium chromate solution in 11 minutes after the start of the experiment.

\section{Conclusion}

1. EMF of the system ranged $0.65 \mathrm{~V}$ to $0.87 \mathrm{~V}$ for all tested anode catalysts (platinum- and ruthenium-coated titanium electrodes, activated carbon electrode in a stainless steel $(18 \mathrm{Cr}-9 \mathrm{Ni})$ wire basket, and stainless steel (18Cr-9Ni) electrode, when using carbon steel as a cathode. However, for platinum- and ruthenium-coated titanium anodes in a number of experiments, a noticeable voltage drop was observed during the process, which was not observed for an activated carbon anode and a stainless steel $(18 \mathrm{Cr}-9 \mathrm{Ni})$ anode.

2. Carbon steel is well established as a cathode catalyst. When using this catalyst, EMF of fuel cell was 0.7-0.8 V, which is typical for alcohol fuel cells. When using a stainless steel $(18 \mathrm{Cr}-9 \mathrm{Ni})$ cathode, EMF of the system was less, almost twice (the data are not shown).

3. Introduction of sodium hypochlorite, hydrogen peroxide, potassium chromate in the bottom phase of the system led to a decrease in the EMF of the system. Apparently, this is due to the fact that the introduction of additional oxidant into the system led to a decrease in the oxygen depolarization of the process and to a shift in the cathode potential to the positive region, i.e. to reduce the difference between of the anode and cathode potentials.

4. Due to the fact that both electrodes were in the passivity region, the exchange currents in the system were small. The additional introduction of the oxidant led only to a short-term increase of the current in the system, which was explained by the cumulative effect of the additional oxidant, and was accompanied by a further decrease in the EMF.

The studies were carried out with the financial support of the Russian Foundation for Basic Research (RFBR) in the framework of the scientific project No. 19-58-60002.

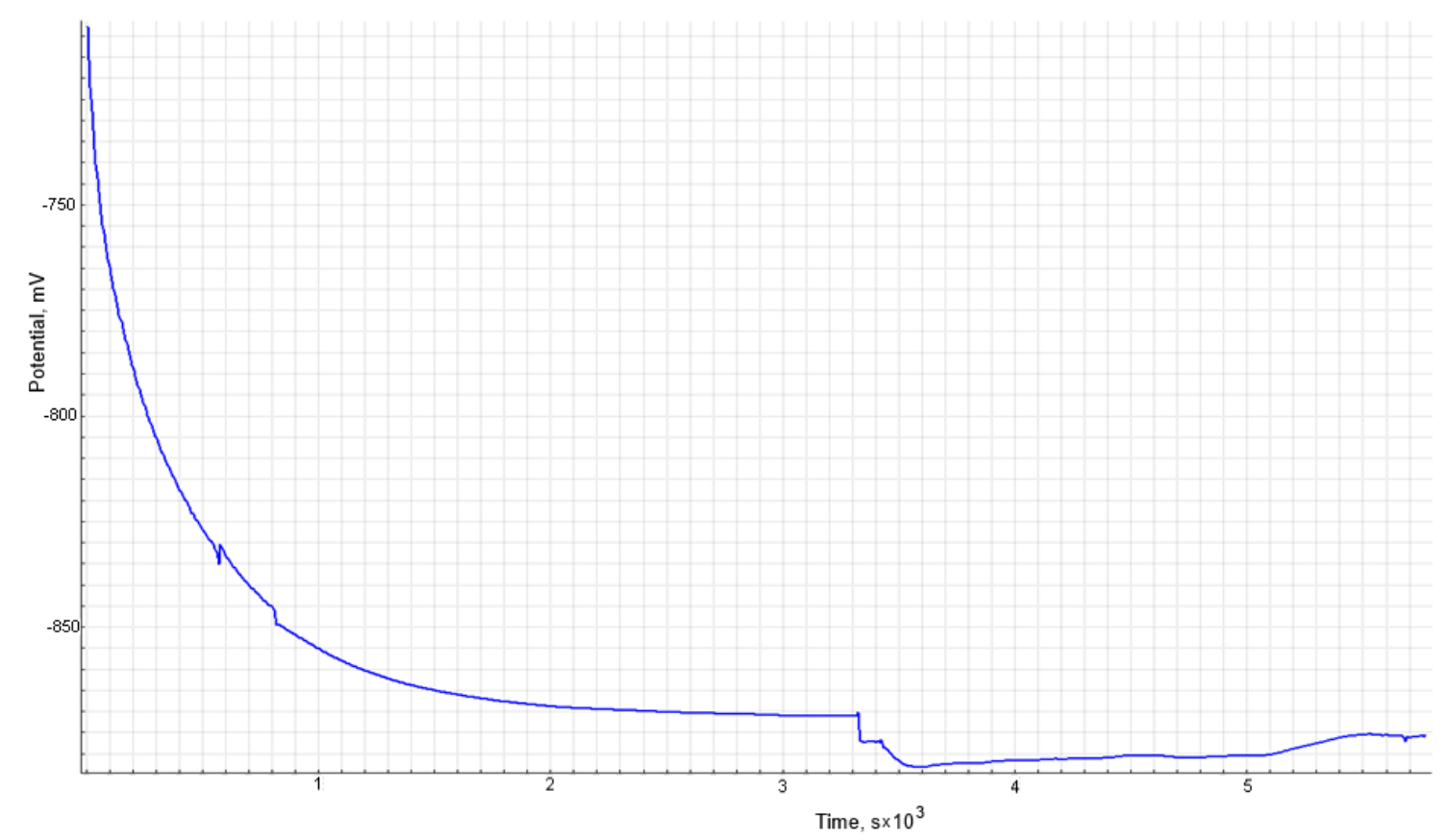

Fig. 9. Change in EMF of a fuel cell with a stainless steel anode and a carbon steel cathode. 


\section{References}

[1] E.R. Choban, P. Waszczuk, P.J.A. Kenis, Electrochem. Solid-State Lett., 8, A348-A352 (2005).

[2] D.T. Whipple, R.S. Jayashree, D. Egas, N. AlonsoVante, P.J.A. Kenis, Electrochim. Acta., 54, 43844388 (2009).

[3] Q. Yi, Q. Chen, Z. Yang, J. Power Sources., 298, 171-176 (2015).

[4] A.J. Armenta-González, R. Carrera-Cerritos, A. Moreno-Zuria, L. Álvarez-Contreras, J. LedesmaGarcía, F.M. Cuevas-Muñiz, L.G. Arriaga, Fuel. 167, 240-247 (2016).

[5] J. Maya-Cornejo, E. Ortiz-Ortega, L. ÁlvarezContreras, N. Arjona, M. Guerra-Balcázar, J. Ledesma-García, L.G. Arriaga, Chem. Comm. 51, 2536-2539 (2015).

[6] C.A. López-Rico, J. Galindo-de-la-Rosa, E. OrtizOrtega, L. Álvarez-Contreras, J. Ledesma-García, M. Guerra-Balcázar, L.G. Arriaga, N. Arjona, Electrochim. Acta. 207, 164-176 (2016).

[7] B. Chen, D.Y.C. Leung, J. Xuan, H. Wang, J. Power Sources, 336, 19-26 (2016).

[8] W. Sung, J.-W. Choi, J. Power Sources, 172, 198208 (2007).

[9] M.L. Perry, T.F. Fuller, J. Electrochem. Soc., 149, S59-S-67 (2002).

[10] "Quantum": the energy of victory, Moscow, MAKD, 184 (2009).

[11] F. Bidault, A. Kucernak, J. Power Sources, 195, 2549-2556 (2010).

[12] J.C. Abrego-Martínez, Y. Wang, A. Moreno-Zuria, Q. Wei, F.M. Cuevas-Muñiz, L.G. Arriaga, S. Sun, M. Mohamedi, Electrochim. Acta., 297, 230-239 (2019).

[13] J.C. Abrego-Martínez, A. Moreno-Zuria, Y. Wang, F.M. Cuevas-Muñiz, L.G. Arriaga, S. Sun, M. Mohamedi, Int. J. Hydrogen Energy., 42, 2196921975 (2017).

[14] J.C. Abrego-Martínez, A. Moreno-Zuria, F.M. Cuevas-Muñiz, L.G. Arriaga, S. Sun, M. Mohamedi, J. Power Sources., 371, 10-17 (2017).

[15] M.J. Estrada-Solís, J.C. Abrego-Martínez, A. Moreno-Zuria, L.G. Arriaga, S. Sun, F.M. CuevasMuñiz, M. Mohamedi, Int. J. Hydrogen Energy. 44, 18372-18381 (2019).

[16] Q. Wang, F. Chen, Y. Liu, T.T. Gebremariam, J. Wang, L. An, R.L. Johnston, J. Power Sources, 404, 106-117 (2018).

[17] X. Yu, E.J. Pascual, J.C. Wauson, A. Manthiram, J. Power Sources, 331, 340-347 (2016).

[18] M.R. Tarasevich, E.S. Davydova, Rus. J. Electrochem., 52, 193-219 (2016).

[19] A.N. Frumkin, V.S. Bagotsky, Z.A. Iofa, B.N. Kabanov, Kinetics of electrode processes, Moscow, MGU, 319 (1952).

[20] V.S. Pakhomov, A.A. Shevchenko, Chemical resistance of materials and corrosion protection, Moscow, Khimia, KolosS, 444 (2009). 